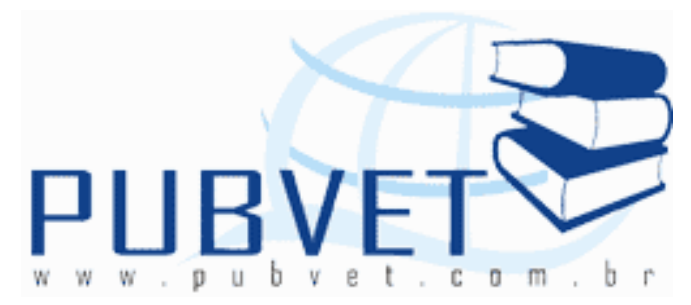

PUBVET, Publicações em Medicina Veterinária e Zootecnia.

\title{
Characterization of beef consumption in the elderly population in the municipality of Santa Maria - RS, Brazil
}

\author{
Jackeline Karsten Kirinus ${ }^{1 *}$; Aline Zulian²; Renius de Oliveira Mello ${ }^{3}$; Andréa \\ Cristina Dörr ${ }^{4}$; José Laerte Nörnberg ${ }^{3}$
}

${ }^{1}$ Aluna de doutorado do Programa de Pós-graduação em Ciência e Tecnologia dos Alimentos da Universidade Federal de Santa Maria (PPGCTA_UFSM).

*E-mail: jackeline.kirinus@gmail.com. Autor para correspondência.

${ }^{2}$ Aluna de graduação do curso de economia da UFSM, Grupo de Pesquisa em Agronegócios (GPA).

${ }^{3}$ Professor Adjunto PPGCTA_UFSM.

${ }^{4}$ Professora Adjunta UFSM, Departamento de Ciências Econômicas, GPA.

\section{Abstract}

This study aimed to evaluate how the economic and social characteristics influence beef consumption by elderly population from the city of Santa Maria, Rio Grande do Sul, Brazil. Brazil is the second largest producer of beef and has shown an increased consumption of it, mainly due to factors such as changes in the dietary habits and in the socioeconomic conditions. There were applied structured forms for a sample of 138 elderly ( 70 men and 68 women), with the average age of respondents of 68.4 years. The attributes considered important by the elderly who buy first choice beef were tenderness $(42.5 \%)$, taste $(32.5 \%)$, followed by the visible fat $(12.5 \%)$. Also, the level of education 
influences negatively the purchase of first choice beef; and positively the level of income of the interviewed elderly. Thus, other variables may influence the purchase of the cuts of first choice and the level of income. Therefore, it is necessary to invest in beef consumption by elderly consumers, placing emphasis on the marketing of products with superior quality.

Keywords: behaviour, consumer, dietary habit.

\section{Caracterização do consumo de carne bovina na população idosa no Município de Santa Maria - RS, Brasil}

\section{Resumo}

O objetivo deste estudo foi avaliar de que forma as características econômicas e sociais influenciam o consumo da carne bovina na população idosa da cidade de Santa Maria, Rio Grande do Sul, Brasil. O Brasil é segundo maior produtor mundial de carne bovina e tem demonstrado um consumo crescente deste alimento, principalmente devido a fatores como mudanças no hábito alimentar e condições socioeconômicas. Foram aplicadas formas estruturadas para uma amostra de 138 idosos (70 homens e 68 mulheres), com idade média dos entrevistados de 68,4 anos. Os atributos considerados importantes pelos idosos que compram carne de primeira foram maciez $(42,5 \%)$, sabor $(32,5 \%)$, seguido da gordura visível (12,5\%). Também, observou-se que o nível de escolaridade influencia negativamente a compra de carne bovina de primeira escolha, e positivamente o nível de renda dos idosos. Assim, outras variáveis podem influenciar a compra de cortes de primeira escolha e o nível de renda. Portanto, é necessário investir em consumo de carne bovina por consumidores idosos, dando ênfase à comercialização de produtos com qualidade superior.

Palavras-chave: comportamento, consumidor, hábito alimentar.

\section{Introduction}

In Brazil, the beef cattle represents great economic importance. Among the factors contributing to the increase in beef production, we cited the greater 
KIRINUS, J.K. et al. Characterization of beef consumption in the elderly population in the municipality of Santa Maria - RS, Brazil. PUBVET, Londrina, V. 7, N. 14, Ed. 237, Art. 1564, Julho, 2013.

number of exports, continued growth in the domestic demand for beef and higher purchasing power of the consumers (FAO, 2011; USDA, 2012). In this sense, the change in the pattern of food consumption in general is due to, large part, socioeconomic and demographic changes (Rijswijk et al., 2008)

In the Brazilian case, variables such as income level, urbanization, women's education and family composition are essential to the consumption. Thus, having knowledge of customers profiles and of the factors taken into account in the moment of purchase, are of utmost importance for customer satisfaction, and consequently for the success of the enterprise. However, a key factor in ensuring the success and competitiveness of an organization is to know the preference of consumers, how they make purchasing decisions and what is the use of the offered products (Barcellos et al., 2012).

In this sense, the elderly, particularly older ones, are part of the fastest growing segment of the Brazilian population. Between 1991 and 2000 the number of inhabitants over 60 years of age increased 2.5 times (35\%) compared with the rest of the country population (14\%) (UNDESA, 2010). This growth has not been accompanied in the same proportion by epidemiological studies on the elderly.

Several studies involving the behaviour of the consumer of beef have been already conducted in the country (Barcellos et al., 2012). However, no study of this nature was held in Santa Maria city, RS, and region. Due to the particularities of each market and to the different behaviours of consumers from one geographic location to another, studying the characteristics of regional consumption significantly contribute towards understanding what are the consumer demands for products and which are the specific features sought by them.

Therefore, regarding the lack of studies investigating the preferences elected by the consumers, the objective of this study was to evaluate how the economic and social characteristics influence the consumption of beef in the elderly population of the city of Santa Maria, Rio Grande do Sul, Brazil. 
KIRINUS, J.K. et al. Characterization of beef consumption in the elderly population in the municipality of Santa Maria - RS, Brazil. PUBVET, Londrina, V. 7, N. 14, Ed. 237, Art. 1564, Julho, 2013.

\section{Materials and methods}

To conduct this study, a field research with primary data collection were performed through structured forms applied to the elderly in Santa Maria, Rio Grande do Sul, Brazil from Mar. to Apr. 2011 (Latitud: 290 41' 03" S and Longitud: $53^{\circ} 48^{\prime} 25^{\prime \prime} \mathrm{W}$ ).

The objective was to identify characteristics of beef consumption of the population in analysis. The variables that were collected are: 1) socioeconomic characteristics: age, gender, education, income, and 2) characteristics of the cuts: the cuts attributes, frequency of consumption, types of cuts [first choice (rump, topside, tenderloin, rump tail, rump cap, knuckle) and second choice (chop, rib, shoulder, ribs roast)] and purchase decision factors.

After the application of the forms, data were tabulated and analyzed. The analysis was performed through the Statistical Package for Social Sciences - Statistical Package for Social Sciences (SPSS) version 15.0.

The hypotheses of this study consist to compare the beef consumption according to the social and economic characteristics of the elderly population. The means of the variables were calculated in order to check whether there are significant differences at the level of $1 \%, 5 \%$ and $10 \%$, using the Chi-square test. It was also hypnotized whether there is significant difference among the attributes chosen by the elderly population with regards the purchase of first and second choice. Correlation test was also performed aiming at checking whether variables have a positive, negative or none correlation.

Sampling is a statistical tool used when the population (the total set of elements that is seek to analyze) is composed of a very large number of elements, which prevent the access of the entire population to data collection. Thus, a sample is selected, with significant number and characteristic of elements within the population, so that the sample results, are sufficiently informative when infer in conclusions about parameters of the population in analysis (Levy and Lemeshow, 2009).

The simple random sampling technique, for finite and known population was used. Previously to the definition of the sample for effective collection of 
data, a pilot study was performed comprising a group of 33 elderly to obtain information on population in analysis and determine the minimum sample size needed for the research at a confidence level of $95 \%$.

Both pilot study and primary data collection were carried on at the Salvador Isaiah Boardwalk in the centre of Santa Maria, RS. The elderly were randomly selected using a random number generator, so that each person remaining in the population has the same probability of being selected for the sample (Neuman, 2009).

The application of the questionnaires was conducted by a group of experienced interviewers, who explained to consumers its brief characteristics, solving any doubt that might occur before the interviewee answer the questions completely, in accordance with the approval of the ethics committee CAAE number of 06049312.3.0000.5346. Thus, a pattern was obtained and assurance that all questions were answered. The quality of the collected data was satisfactory, considering that the elderly were concerned to detail the answers in depth. Thus, it was managed to lift quite easily, for example, the monthly income (Trespalacios et al., 2005).

The elderly population of Santa Maria, aged 60 years or older is of 26,423 inhabitants (IBGE, 2000). The key variable considered in the pilot study to calculate the sample size is the consumption of beef [mean 1.85 kilograms (kgs), standard deviation $0.288 \mathrm{kgs}$, sampling error 5\%]. The estimated sample size resulted in 138 elderly (Figure 1 ). 


$$
\begin{gathered}
n=\frac{\left(t_{\delta, \frac{a}{2}}\right)^{2} \times s^{2} \times N}{e_{0}^{2}(N-1)+\left(t_{\delta, \frac{a}{2}}\right)^{2} \times s^{2}} \\
n=\frac{2,042^{2} \times 0,288^{2} \times 26423}{0,05^{2} \times(26423-1)+2,042^{2} \times 0,288^{2}} \\
n=137,62 \cong 138 \text { pleoples }
\end{gathered}
$$

where:

$n=$ minimum sample size calculated;

$t_{\delta, \frac{a}{2}}=$ value of $t_{\text {tab }}$ admitting $\alpha=5 \%$

$s^{2}=$ variance obtained from the pilot sample;

$N=$ population size;

$e_{0}^{2}=$ square sampling error, with the data obtained from the pilot sample.

Figure 1. Equation for sampling calculation

\section{Results and discussion}

The elderly population has been growing rapidly in Brazil (UNDESA, 2010). In this regards, the eating habits of beef consumption of 138 respondents (70 men and 68 women) show that, the average age of respondents was of 68.4 years (standard deviation of 6.33 years).

Eight levels of education were found, including: illiterate $(2.1 \%)$, incomplete primary school (33.6\%), complete primary school (16.1\%) incomplete high school $(7.7 \%)$, complete high school $(21.7 \%)$, incomplete third grade $(1.4 \%)$, complete third grade $(15.4 \%)$, complete post-graduation $(2.0 \%)$. The highest concentrations are in the range of elementary school and high school graduates, respectively. This result is consistent with the findings 
of Barham et al. (2003) in which the majority of respondents have some level of schooling, and thus, when older consumers have some level of knowledge, it becomes more difficult to be influenced and persuaded.

Beef is of great importance as a source of protein that is present among the main items that compose the consumption basket of the Brazilian population (Monteiro and Caswell, 2004). In the meantime, domestic protein consumption is increasing, per capita beef consumption has increased $5.2 \%$ since 2006 (from $36 \mathrm{kgs}$ to $38 \mathrm{kgs}$ ) in 2012 (Canfax, 2012). Moreover, the consumption depends on some factors such as age of the consumer, preference, purchasing power, education and final price of the product (Curasi, 1995).

In this study, the respondents have the habit of consuming beef, on average, 19 days per month (standard deviation of 8.07 days). On the one hand, elderly who buy beef cuts of first and second choice have no significant difference in age. On the other hand, those who buy cuts of first choice receive a higher income in Reais compared to respondents who buy cuts of second choice (Table 1).

Table 1. Stratification of the types of beef consumed according to the social and economic characteristics of the elderly population

\begin{tabular}{|c|c|c|c|c|c|}
\hline \multirow[b]{2}{*}{ Variables } & \multicolumn{2}{|c|}{ First choice beef } & \multicolumn{2}{|c|}{ Second choice beef } & \multirow{2}{*}{$\begin{array}{c}\text { Chi, t } \\
\text { test } \\
\text { Sig }\end{array}$} \\
\hline & Average & $\begin{array}{l}\text { Standard } \\
\text { Deviation }\end{array}$ & Average & $\begin{array}{l}\text { Standard } \\
\text { Deviation }\end{array}$ & \\
\hline Age in years & 67.89 & 5.91 & 68.97 & 6.57 & 0.118 \\
\hline Income in Reais & 3040.00 & 1782.13 & 1441.5 & 1107.86 & $0.000^{a}$ \\
\hline Scholarity in years & 3.07 & 1.76 & 2.70 & 1.98 & $0.005^{a}$ \\
\hline Quantity in kg of beef & 1.81 & 1.23 & 2.87 & 1.27 & 0.345 \\
\hline Price per kg in Reais & 12.90 & 4.13 & 11.36 & 5.03 & 0.254 \\
\hline
\end{tabular}

Legend: ${ }^{a}$ Significant values at $5 \%$ of probability

Source: Elaborated by the authors with base in the research results. 
KIRINUS, J.K. et al. Characterization of beef consumption in the elderly population in the municipality of Santa Maria - RS, Brazil. PUBVET, Londrina, V. 7, N. 14, Ed. 237, Art. 1564, Julho, 2013.

Elderly with higher educational level buy fewer cuts of first choice (negative relationship where the Pearson correlation is $-0.135, p<0.01$ ) and those with higher educational level have higher income (positive relationship where the Pearson correlation is $0,210, p<0.01$ ). Despite the fact that both results are significant it shows a weak association between the variables. Thus, other variables may influence the purchase of the first choice and the level of income.

A great diversity of factors that contribute in the change of eating habits of the elderly are perceived such as the average of income (in Reais) and the years of schooling with regards to the type of cut $(p<0.01)$. The elderly buy a larger quantity of beef of second choice (2.87 kgs per month) and pay on average, R\$11.36 per kgs. Miller et al. (2001) and Pinto et al. (2008) found that the price and nutritional quality are attributes considered more important in the food choice at the time of purchase.

Elderly who buy cuts of first choice $(p<0.05)$ the most important attributes are the beef tenderness $(42.5 \%)$, taste $(32.5 \%)$, followed by the visible fat (12.5\%) (Table 2 ). Factors such as good appearance, adoption of traceability procedures, hygiene at the point of purchase, nutritional quality and tenderness are taken into account by the consumer while considering meat with high quality standard (Barcellos et al., 2012).

Comparing the first choice beef based on the characteristics of colour $[R \$ 1,300.00]$, visible fat $[R \$ 2,307.15]$, tenderness $[R \$ 2,624.64]$, preparation $[R \$ 1,909.91]$, taste $[R \$ 1,275.00]$ it is possible to verify that elderly with higher income $[R \$ 2,624.64]$ are those who choose beef for its tenderness. However, elderly who choose the cut by its taste are those that have the lowest income $[R \$ 1,275.00](p<0.10)$.

The ten cuts of beef most consumed by respondents were: rib $(27.8 \%)$, topside $(11.8 \%)$, rump cap $(9.0 \%)$, tenderloin $(8.3 \%)$, rump $(8.3 \%)$, rump tail $(7.6 \%)$, chop $(6.9 \%)$, shoulder $(5.6 \%)$, knuckle $(5.6 \%)$, ribs roast $(2.1 \%)$ and others $(7.0 \%)$. The results on preferences by for tender and flavourful cuts are consistent with those found by Delgado et al. (2006). 
KIRINUS, J.K. et al. Characterization of beef consumption in the elderly population in the municipality of Santa Maria - RS, Brazil. PUBVET, Londrina, V. 7, N. 14, Ed. 237, Art. 1564, Julho, 2013.

Table 2. Characteristics of the beef and their influences in purchasing decision

\begin{tabular}{lcc}
\hline \multirow{2}{*}{ Characteristics of the beef } & \multicolumn{2}{c}{ Types of beef } \\
\cline { 2 - 3 } & First choice beef* & Second choice beef** \\
\hline Colour & 0.0 & 1.0 \\
Visible fat & 12.5 & 7.2 \\
Tenderness & 42.5 & 20.6 \\
Price & 2.5 & 0.0 \\
Preparation & 7.5 & 9.3 \\
Taste & 32.5 & 59.8 \\
Other & 2.5 & 2.1 \\
Total & 100.0 & 100.0 \\
\hline
\end{tabular}

Legend: *Pearson Chi ${ }^{2}=0,038$ (significant at $5 \%$ ) and $* * 0,112$

Source: Elaborated by the authors with base in the research results.

Consumers are seeking foods with good visible features in addition to a healthy, balanced and safe diet. In this sense, the quality of food is essential for the healthy consumption and for the product acceptance in the market (Dörr and Grote, 2010; Barcellos et al., 2012). Nevertheless, factors as taste, tenderness and fat are essential when purchasing beef.

According to Grunert (2005), the available foods for consumption by individuals cannot be subjected to any kind of risk by contamination, quality problems or other due to the expiry date. Therefore, the quality must go beyond the manufacture of the meat product, being necessary to guide the processes of packaging, transport and display of the product to reach the final consumer, thus promoting food safety and certification.

The elderly population in Brazil is increasing at higher levels than those observed in other strata of the population. At the same time, there is an improvement in income and education levels of the population. In this sense, 
KIRINUS, J.K. et al. Characterization of beef consumption in the elderly population in the municipality of Santa Maria - RS, Brazil. PUBVET, Londrina, V. 7, N. 14, Ed. 237, Art. 1564, Julho, 2013.

there is a greater concern with quality requirements of the meat product to be consumed.

\section{Conclusions}

The level of education influences negatively the purchase of first choice beef, and positively the level of income of the interviewed elderly.

The most important attributes considered on the decision of purchase of this beef were tenderness and taste. It is also noteworthy that the elderly do not consider colour as an important attribute in purchasing decisions.

It is necessary to study the consumption of beef in the segment of elder consumers, especially with emphasis on guidance and marketing of products.

\section{Acknowledgements}

To CAPES for a doctorate scholarship granted to the Post-Graduation Program in Science and Food Technology of the Federal University of Santa Maria.

To the members of the Integrated Centre of Development in Analytical Laboratory (NIDAL) and to the Agribusiness Research Group (GPA) of the Federal University of Santa Maria.

\section{References}

Barcellos, J.O.J.; Abicht, A.M.; Brandão, F.S.; Canozzi, M.E.A.; Collares, F.C. Consumer perception of Brazilian traced beef. Revista Brasileira de Zootecnia, v. 41, p. 771-774, 2012.

Barham, B.L.; Brooks, J.C.; Blanton, J.R.; Herring, A.D.; Carr, M.A.; Kerth, C.R.; Miller, M.F. Effects of grow thim plants on consumer perceptions of meat tenderness in beef steers. Journal of Animal Science, v. 81, p. 3052-3056, 2003.

Canfax Research Services (Canfax). The Global Cattle Cycle [Online]. 2012. Available at http://www.canfax.ca/Samples/The\%20Global\%20Cattle\%20Cycle\%20Sept\%202012.pdf (verified 16 January 2013).

Curasi, C.F. Male senior citizens and their shopping preferences. Journal of Consumer Marketing, v. 12, p. 123-133, 1995.

Delgado, E.F.; Aguiar, A.P.; Ortega, E.M.M.; Spoto, M.H.F.; Castillo, C.J.C. Brazilian consumers' perception of tenderness of beef steaks classified by shear force and taste. Scientia Agricola, v. 63, p. 232-239, 2006.

Dorr, A.C.; Grote, U. The role of certification in the Brazilian fruit sector. Revista de Economia Contemporânea, v. 13, p. 539-571, 2010. 
KIRINUS, J.K. et al. Characterization of beef consumption in the elderly population in the municipality of Santa Maria - RS, Brazil. PUBVET, Londrina, V. 7, N. 14, Ed. 237, Art. 1564, Julho, 2013.

Food and Agriculture Organization (FAO). Food outlook: global market analysis [Online]. 2011. Available at: http://www.fao.org/docrep/014/al978e/al978e00.pdf (verified 10 June 2012).

Grunert, K.G. Food quality and safety: consumer perception and demand. European Review of Agricultural Economics, v. 32, p. 369-391, 2005.

Instituto Brasileiro de Geografia e Estatística - Brazilian Institute of Geography and Statistics (IBGE). Profile of elderly householders in Brazil. 2000. Available at: http://www.ibge.gov.br/home/estatistica/populacao/perfilidoso/default.shtm (verified 21 February 2011) (in Portuguese).

Levy, P.S.; Lemeshow, S. Sampling of populations, solutions manual: methods and applications. 4nd edn. Wiley: New York, USA. 2009.

Miller, M.F.; Carr, M.A.; Ramsey, C.B.; Crockett, K.L.; Hoover, L.C. Consumer thresholds for establishing the value of beef tenderness. Journal of Animal Science, v. 79, p. 3062-3068, 2001.

Monteiro, D.M.S.; Caswell, J.A. The economics of implementing traceability in beef supply chains: trends in major producing and trading countries [Online]. 2004. Available at: http://dx.doi.org/10.2139/ssrn.560067 (verified 16 January 2013).

Neuman, W.L. Social research methods: qualitative and quantitative approaches. 7th edn. Pearson: Toronto, Canada. 2009.

Pinto, M.M.B.; Camargo, M.E.; Guazzelli, F.V.; Malafaia, G.C. Identificação de elementos do processo de decisão de compra dos consumidores de carne bovina no município de Vacaria-RS. Pubvet, v. 2, n. 40, ed. 51, art. 2, 2008.

Rijswijk, W.; Frewer, L.J.; Menozzi, D.; Faioli, G. Consumer perception of traceability: a crossnational comparison of the associated benefits. Food Quality and Preference, v. 19, p. 452464, 2008.

Trespalacios, J.A.; Vázquez, R.; Bello, L. Investigación de mercados, métodos de recogida y análisis de información para la toma de decisiones en marketing. Thomson: Madrid, Spain. 2005.

United Nations Department of Economic and Social Affairs (UNDESA). Population division world population prospects: the 2010 [Online]. 2010. Available at: http://esa.un.org/unpd/wpp/Documentation/pdf/WPP2010 Volume-II DemographicProfiles.pdf (verified 21 January 2013).

United States Department of Agriculture (USDA). Foreign Agricultural Service: Global Agricultural Information Network. Washington, D.C [Online]. 2012. Available at: http://gain.fas.usda.gov/Recent\%20GAIN\%20Publications/Livestock\%20and\%20Products\%20 Semi-annual Brasilia Brazil 1-3-2012.pdf (verified 21 January 2013). 